\title{
Withholding tax on interest: Who has the withholding obligation?
}

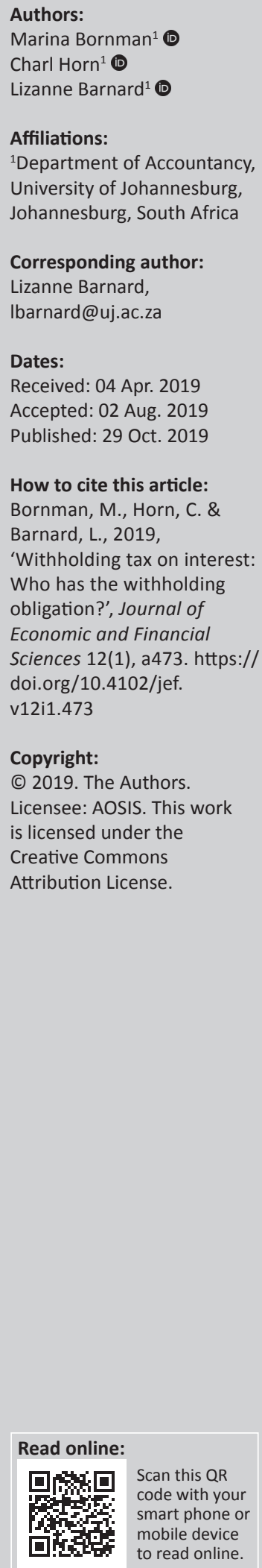

Orientation: Non-residents receiving interest from a South African source will be taxable in terms of the gross income definition in the South African Income Tax Act. Effective 01 March 2015, new provisions for withholding of tax on interest (WTI) to non-residents were incorporated in the Act with the purpose of simplifying the collection of tax from non-residents.

Research purpose: This article aimed to seek clarity on who 'the person is who makes payment' of the interest in order to suggest an amendment to the Act.

Motivation for the study: When dealing with debt instruments, the issuer of the instrument and the 'payer' of the interest might not always be the same person as intermediaries might be involved in the transactions. The provisions on WTI do not clarify who has the withholding obligation in the case of an intermediary, and uncertainty may therefore arise on who the 'payer' of the interest is.

Research approach/design and method: Using a doctrinal method, the article reviewed and interpreted South African legislation and commentary related to the topic and also turned to international legislation dealing with WTI for guidance.

Main findings: It was found that the only person who would be in a position to withhold the withholding tax is the person who is seen as the last client-facing entity or intermediary.

Practical/managerial implications: Two suggestions are offered with regard to amending the provisions on WTI, namely to split the withholding obligation between the issuer and the intermediary and to define 'intermediary'.

Contribution/value-add: This study provides clarity on 'who the payer of the interest' is on whom the withholding obligation rests.

Keywords: withholding tax; interest; non-resident; dividends tax; regulatory intermediary.

\section{Background}

From the definition of 'gross income' in section 1 of the South African Income Tax Act No. 58 of 1962 (hereafter referred to as 'the Act'), it is clear that interest received by or accrued to a non-resident will form part of their gross income if it is sourced within the Republic of South Africa (hereafter referred to as 'SA'):

'[G]ross income', in relation to any year or period of assessment, means -

(ii) in the case of any person other than a resident, the total amount, in cash or otherwise, received by or accrued to or in favour of such person from a source within the Republic.

A non-resident is any person who is not a 'resident' as defined in section 1 of the Act.

Following the above definition of gross income, it can be said that a non-resident receiving interest from a South African source will be taxable on such interest.

In terms of section 9(2)(b)(ii) of the Act, interest is deemed to be from a South African source for the non-resident where that interest is utilised or applied in SA by any person of any funds in terms of any form of interest-bearing arrangement. If the non-resident is then taxable in SA on interest deemed from a South African source, they can further qualify for an income tax exemption with regard to interest paid to non-residents in accordance with section 10(1)(h) of the Act. 
They shall be exempt from normal tax in terms of section 10(1)(h):

[A]ny amount of the interest which is received by or accrues to any person that is not a resident, unless:

(1) that person is a natural person who was physically present in the Republic for a period exceeding 183 days in aggregate during the twelve-month period preceding the date on which the interest is received or accrues by or to that person; or

(2) the debt from which the interest arises is effectively connected to a permanent establishment of that person in the Republic.

This exemption results in the interest earned by non-residents not being subject to normal tax and therefore has the intention of attracting non-resident debt flows to SA (National Treasury 2010). Ger (2015) states that this exemption is prohibited if the non-resident lenders actively take an interest in the South African economy through specified channels. It is highlighted in section 10(1)(h) of the Act that SA can only tax interest (in terms of normal income tax principles) paid to nonresident lenders who create business in SA through permanent establishments (which are essentially fixed places of business) or non-residents who were physically present in SA for more than 183 days of the tax year.

In 2010 however, the South African government noted the concern that 'the current blanket interest exemption does not achieve a fair balance between the attraction of foreign debt capital and the need to protect the tax base against potential erosion' (National Treasury 2010). The exemption is also not in line with global practice and Ger further notes that foreign debt had an unnecessary tax advantage over local debt. The proposal was thus made to introduce a withholding tax on interest paid to foreigners (Ger 2015).

A withholding tax is used as a mechanism to enable the collection of taxes from non-residents. This means that a resident payer has the obligation to withhold a certain percentage of tax from payments made to a non-resident (Davis Tax Committee 2016).

The purpose of this Withholding Tax on Interest (WTI) was to strike a balance between the necessity of bringing in outside debt wealth and the duty to protect the tax base against possible disintegration as the interest exemption under section 10(1)(h) of the Act did not accomplish a reasonable economic offset (National Treasury 2010).

\section{Research design}

This article used an interpretivist paradigm. It is explained by Riyami (2015:413) that an event can have various explanations and that interpretivism seeks to obtain a more in-depth understanding of the event and its intricacy within its exclusive situation, rather than generalising with regard to an entire population. This paradigm is appropriate because the researchers will be analysing and interpreting local legislative as well as foreign legislative provisions in order to seek an in-depth understanding of who the person is who must make the payment of the withholding tax to South African Revenue Service (SARS).

A qualitative approach was used in this study to address the research objectives that are associated with an interpretivist paradigm as highlighted by Rossman and Rallis (2003:35). The present article aims to give meaning to certain concepts by investigating only textual data such as legislation and other written documents, and presents findings in comprehensive descriptions using words. Therefore, a qualitative approach was deemed necessary for this study.

The doctrinal research method is predominant in this article. Hutchinson and Duncan (2012:84) described the doctrinal method as a union of different rules, principles, norms, interpretative strategies and qualities. This method explains, articulates or supports a section of the law within a bigger framework of the law. Furthermore, it represents the exact procedure of recognising, analysing, organising and blending legislative provisions, court rulings and commentary (Mckerchar 2008:18).

The technique for doctrinal research is often associated with the learning or studying of legislative writings as highlighted by Knight and Ruddock (2008), and for this reason, the researchers deem it to be an appropriate method because the research method entails analysing and interpreting legal work such as legislative provisions and legal commentary.

The data analysed in this study comprised the South African Income Tax Act; provisions on withholding taxes from the Income Tax Act of the United Kingdom (UK) and the Internal Revenue Code of the United States of America (USA); commentaries and guidelines published by the National Treasury, SARS and foreign tax authorities; and academic articles on the topic of withholding taxes.

Purposive sampling was used to select the two countries' legislative provisions on withholding taxes, namely that of the UK and the USA. Their legislative provisions and legal guidelines clarify the research problems identified and the guidelines derived from analysing their provisions give sufficient substance to make recommendations in the South African context.

Data analysis was performed as follows: the meaning of 'the person who makes payment' was analysed critically and compared to similar provisions in the Act that apply either the exact phrase or similar phrases. In addition, published guidelines issued by SARS on how it has interpreted the issue were consulted to give meanings to the phrase.

It is important to note that the principle of what is being compared (namely the meaning of 'the person who makes the payment') is the same in nature even though the legislative provisions apply to different transactions. Furthermore, foreign legislation and commentary were used to highlight how the UK and USA have clarified this concept. 


\section{Overview of the withholding tax on interest in South Africa}

Withholding Tax on Interest was legislated with effect from 01 March 2015 and is subject to certain exemptions, a final tax applied against interest specifically paid to foreign persons. The WTI provision is the only tax that a non-resident person will be liable for and therefore the amount received as interest will be fully exempted from normal tax in terms of section 10(1) as explained earlier, and no further tax liability will flow to the fiscus from the interest.

The WTI provisions are contained in sections $50 \mathrm{~A}-50 \mathrm{H}$ of the Act. To clarify to what extent interest applies to the provisions of WTI, the term 'interest' is defined in section 50A of the Act and applies only to paragraphs (a) and (b) of the definition of 'interest' under section 24J(1) of the Act.

The definition of 'interest' under paragraphs (a) and (b) of section $24 \mathrm{~J}(1)$ states that interest includes:

(a) [G]ross amount of any interest or similar finance charges, discount or premium payable or receivable in terms of or in respect of a financial arrangement

(b) amount (or portion thereof) payable by a borrower to the lender in terms of any lending arrangement as represents compensation for any amount to which the lender would, but for such lending arrangement, have been entitled to.

It is important that the withholding tax must be levied on South African source interest payable to a non-resident only. In terms of section $50 \mathrm{~B}(1)$ of the Act:

[T] here must be levied.... tax to be known as the withholding tax on interest... of any interest that is paid by any person to or for the benefit of any foreign person to the extent that the amount is regarded as having been received or accrued from a source within the Republic in terms of section 9(2)(b).

If the source of the interest does not arise from within SA, WTI is not applicable. The meaning of the word 'source' is not defined in the Act although there are deeming provisions relating to interest. According to section 9(2)(b)(ii) of the Act, interest is deemed to be from a South African source where that interest is received with respect to the use or application in SA, by any person of any funds in terms of any form of interest-bearing arrangement.

Numerous exemptions to WTI exist in terms of section 50D of the Act and the SARS has highlighted three broad exemption categories: the person paying the interest, the instrument giving rise to the interest and the non-resident beneficiary of the interest (SARS 2017).

According to section $50 \mathrm{C}(1)$ of the Act, a foreigner who receives the interest amount is liable for the tax on the basis that it has been received by or accrued to that foreigner from a South African source, but section 50E(1) of the Act explains that the tax on the interest must be withheld by 'any person who makes payment of any amount of interest to or for the benefit of a foreign person'. Although not specifically stated in the WTI provisions, the 'person who makes payment' can also be referred to as the 'withholding agent' in terms of section 156 of the Tax Administration Act (TAA) (No. 28 of 2011).

Section $50 \mathrm{~B}(2)$ of the Act deems interest to be paid on the 'earlier of the date on which interest is paid or becomes due and payable' and according to section $50 \mathrm{~F}(2)$ of the Act, it needs to be paid over to SARS in the month following the month in which the interest is deemed to be paid.

Section $50 \mathrm{E}(1)$ of the Act denotes that the 'person who makes payment' of any amount of interest to, or for the benefit of, a foreign person has the withholding obligation. Yet, it is unclear as to whom this person relates because given the specific situation, the issuer can make the initial interest payment to an intermediary and the intermediary (who acts on behalf of the holder of the instrument) can transfer the same interest payment to the holder.

The relevance of knowing who the person is making the interest payment is important because it creates a withholding obligation on that person to withhold the correct amount of withholding tax in terms of section $50 \mathrm{E}(1)$ of the Act. The uncertainty of the phrase should not create a situation where both the issuer and intermediary withhold tax because of a misinterpretation of the legislation or, conversely, result in a failure from either the issuer or the intermediary of withholding.

\section{Research problem and objective}

The concept of a 'withholding agent' is not defined in any withholding tax legislation in the Act. However, it is defined in section 156 of the TAA to mean 'a person who must under a tax Act withhold an amount of tax and pay it to SARS'. The definition assists in understanding what is labelled as a person who has the withholding obligation, assuming the legislation is clear on who the person is who must withhold. Unfortunately, the definition does not lend assistance in the WTI framework where there is uncertainty as to who has the withholding obligation.

The concern with respect to the withholding agent is therefore the lack of clarity in section $50 \mathrm{E}(1)$ of the Act when reference is made to the 'person who makes payment'. It is not clear whether the phrase 'person who makes payment' refers to (1) the issuer of the debt instrument who originally makes the interest payment, even though the issuer might or might not know who the foreigner is that is entitled to the interest; or (2) the person who acts in the capacity of an intermediary between the issuer and foreigner and has the fiduciary duty of transferring the interest amount to the foreigner.

It must be stated that the uncertainty does not extend to situations where the issuer of the instrument (the person paying the interest) and the holder of the same instrument (the person receiving the interest) have no intermediary 
between the two parties. In such a case, the interest payment is facilitated directly between the issuer and the holder in which case the issuer would be the person who is making the interest payment and would have the withholding obligation.

The objective of this article is therefore to seek clarity on who 'the person is who makes payment' of any amount of interest in order to suggest an amendment to the Act to possibly eliminate the uncertainty created by this phrase. In order to address this objective, the article reviews similar legislation contained in sections on withholding of dividends tax in the Act and also turns to international legislation dealing with withholding of tax on interest payments for guidance.

\section{Analysis and discussion}

\section{The concept of 'the person who makes payment' in the light of dematerialised instruments}

The person who makes the payment of interest may be the issuer of the debt instrument and thus the person with whom the interest originates. However, it is possible that the issuer of the debt instrument may also make an initial interest payment to an intermediary and the intermediary (who acts on behalf of the holder of the instrument) can transfer the same interest payment to the holder. Horn (2018) explains that this is particularly relevant in the case of a dematerialised instrument. An example to illustrate this could be when a client (the holder) buys a financial instrument through an authorised stockbroker (intermediary).

The purpose of explaining the meaning of dematerialisation and how it operates in practice is to illustrate that when an instrument is in a dematerialised format, the issuer of the instrument will not know who the holder of the instrument is (Horn 2018). This is where regulated intermediaries (RIs) come into play who act as withholding agents between the issuer and the holder. Although dematerialisation applies in both dividend tax and WTI, no clarity is provided in the WTI legislation on intermediaries and therefore a review of dividends tax provisions is applicable in the context of the present article.

Dematerialisation is explained as the procedure whereby physical paper-based certificates of a financial instrument owned by the investor are exchanged with electronic records of possession (STRATE 2017). In order for the financial instrument to shift from the seller to the buyer and the cash to change hands from the buyer to the seller, the process is managed by the Central Security Depository (CSD) together with the assistance of other particular companies that have been given strict consent to perform an assistance function. These are known as Central Securities Depository Participants (CSDPs). A CSD is an organisation entrusted with keeping electronic records of possession concerning financial instruments. These accounts are securely stored in electronic format by the CSD which permits the day-to-day exchange of title rights of the financial instruments from seller to purchaser to occur seamlessly. This results in the issuer of the instrument not knowing the identity of the investor holding the instrument because there is no physical asset register held by the issuer.

When an investor receives an interest or dividend payment flowing from a financial instrument that is in a dematerialised format, the issuer who is obligated to pay the interest or dividends must pay the CSD because it is only the CSD who knows who the beneficial owner of the distribution is. It is therefore practically not possible for the issuer to withhold the WTI because he or she does not even know if the receiver is a non-resident. The CSD will then pass that interest or dividend payment onto the various CSDPs and the CSDPs will pass the distribution (unless the investor resides directly within the CSDP) onto the appropriate financial service provider which 'owns' the investor or has the relationship with the investor. These authorised financial service providers will typically be stockbrokers, asset managers, linked investment service providers and management companies, etc. (Horn 2018).

Considering this, when there has been a payment of interest from a financial instrument to an intermediary, the question arises as to whether the withholding obligation rests on the issuer who makes the actual interest payment (such person being the person 'who makes payment of any amount of interest to or for the benefit of a foreign person' as per section $50 \mathrm{E}(1)$ of the Act). Because the issuer may not know who the holder of the instrument is, it was noted above that this may not be practically possible and it therefore needs to be established whether the withholding obligation perhaps rests on the person (the intermediary) who receives the interest payment on behalf of the holder and transfers that interest amount to the holder. Could the intermediary thus be the person referred to in section 50E(1) of the Act as 'being the person who makes payment of interest'?

\section{Guidance from withholding of dividends tax provisions in the Act}

Interestingly, the Act clarifies the withholding obligation in the case of dividends tax (see sections $64 \mathrm{G}$ and $64 \mathrm{H}$ of the Act) where a financial instrument is in a dematerialised format, yet the same clarity in the WTI legislation is absent.

If one considers the dividends tax legislation in the Act, the legislature clearly defines the concept of a Regulated Intermediary (RI) and splits the withholding obligation on either the company paying the dividend to the beneficial owner or on the RI transferring the dividend to the beneficial owner in terms of sections $64 \mathrm{G}$ and $64 \mathrm{H}$ of the Act. This is because of the fact that the companies paying dividends do not always know who the beneficial owner of the dividend is, in the same way that issuers of interest instruments do not always know who the holder of the interest instrument is. Hence, where the RI faces the beneficial owner of the dividend instead of the company, the RI has the withholding obligation (SARS 2015). 
Briefly, an RI is an organisation that provisionally holds a dividend paid by a company before it is inevitably paid over to the beneficial owner (SARS 2015). The National Treasury explains that RIs were included in the Dividends Tax legislation because RIs were usually the only reliable persons who knew who the enlisted shareholders were of listed companies (specifically on account of uncertificated shares, i.e., dematerialised shares) because the listed shareholders were stored in share registers housed by different RIs (National Treasury 2009). This is a direct result of the way dematerialised instruments operate in the market place.

Section $64 \mathrm{G}(2)$ (c) of the Act specifically states that a company paying a dividend to an RI must not withhold any dividends tax from the payment of that dividend. It is further clarified in section $64 \mathrm{H}(2)(\mathrm{b})$ of the Act that an RI must not withhold any dividends tax from the payment of any dividend if that person to whom the payment is made is another RI.

It is clear that the withholding obligation shifts from person to person and therefore depends on who faces the beneficial owner. It is acknowledged that as dematerialisation also applies in the world of WTI, this principle should equally apply in the WTI legislation. However, there is no mention of the concept of an intermediary in the WTI provisions and it is therefore suggested that the existing WTI legislation could be amended to create certainty as to who is required to withhold. A suggestion is that the legislative changes should replicate the dividends tax legislation in practice, in the sense of defining who is termed to be "withholding agents'.

\section{Guidance from foreign legislation pertaining to withholding taxes}

\section{Legislation pertaining to 'withholding' from the United States of America}

The Internal Revenue Service of the USA has similar withholding tax provisions on non-residents as WTI in SA. In terms of section 1441(a) of the Internal Revenue Code (IRC), it is stated that:

[A]ll persons, in whatever capacity acting...or...having the control, receipt, custody, disposal, or payment of any of the items of income specified in subsection (b)..., of any non-resident alien individual or of any foreign partnership shall...deduct and withhold from such items a tax equal to 30 percent thereof. (US Internal Revenue Services 1986)

It is evident that the withholding obligation is more distinct in this context because it refers to different instances of when withholding can occur. Reference is made to 'whatever capacity' in which one has the 'control, receipt, custody, disposal or payment'. In the light of dematerialised instruments, it is clear that if the person's investments are held by a custodian, it would be the custodian who has the withholding obligation.

A revised publication by the US Department of the Treasury explains that a 'withholding agent' is the person in charge of withholding an amount made to a foreigner and can include the following persons:

[I]ndividuals, corporation, partnership, trust, association, nominee, or any other entity, including any foreign intermediary, foreign partnership, or U.S. branch of certain foreign banks and insurance companies. (US Department of the Treasury 2017)

The US Department of the Treasury further clarifies that although there can be numerous withholding agents, the tax withheld should only take place once by the person making the payment, although different withholding agents might be obligated to withhold. For instance, a pass-through entity that is confident or has reason to suspect that no withholding was performed by the person who paid them the amount is obligated to do the necessary withholding because this entity is also included in the meaning of a withholding agent (USA Department of the Treasury 2017:3).

This clarification document eliminates any uncertainty as to who must withhold and illustrates that the 'last client facing entity', or the intermediary who has the relationship with the ultimate investor, must exercise the withholding responsibility (USA Department of the Treasury 2017). This view is confirmed by Young (2015) in his opinion that an issuer may rely on an intermediary to perform the reporting and withholding pending the responsibility undertaken by the intermediary and the contractual activities between the parties.

\section{Legislation pertaining to 'withholding' from the United Kingdom}

Under section 874(2) of the UK Income Tax Act, the requirement to withhold tax on yearly interest arises when the person makes the interest payment to a non-resident. Even though this wording is very similar to the current WTI in SA, the difference is that Her Majesty's Revenue and Customs (HMRC) clarifies what this position entails in its tax manuals (HMRC 2016).

It is explained by the HMRC (2016) that where the interest payments are processed through various pass-through entities, the requirement to withhold tax only rests on one flow-through entity. This will be the last UK-resident entity in the flow-through chain that transfers the interest payment to the foreign person entitled to the interest.

Furthermore, the HMRC acknowledges that practically speaking, borrowers will not usually know about the withholding responsibility and HMRC will typically look to the final person through whom the interest payment is made to fulfil the withholding obligation (HMRC 2016).

It is evident from the clarification provided in the UK tax manuals that the 'withholding agent' is the last person who has sight of the investor and who is in a position to withhold the correct amount of tax.

\section{Conclusion}

This article aimed to address the objective of providing clarity on who is the 'person who makes payment' of any 
amount of interest in the context of instruments that are dematerialised. It was explained how dematerialised instruments operate in practice to illustrate that the payer of interest may not know who the beneficial owner of the interest yielding instrument is. The article explored the dividends tax provisions for guidance on how it deals with defining who has the withholding obligation. In addition, legislative provisions from the USA and UK pertaining to withholding taxes were reviewed to determine their interpretation of who is the 'person who makes payment'.

The common principle gained from the analysis of the Dividends Tax provision and the US and UK provisions is that in order to practically withhold the correct amount of withholding tax before payment is made to the foreigner, the only person who would be in a position to do so is the person who is seen as the last client-facing entity or intermediary. It is the person who has the relationship with the non-resident and is in a position to determine whether withholding applies.

\section{Recommendations}

It is recommended that the existing provisions in WTI should be amended to reflect two specific changes in order to eliminate the uncertainty created by the phrase that the 'person who makes payment' needs to withhold the necessary tax.

Because of the possibility of dematerialised instruments, there may be instances where only the intermediary interposing the issuer and foreign holder of the instrument will know who the foreign person is who is entitled to the interest (i.e. instruments that have been dematerialised and where the interest payments will be paid through the various custodians). Therefore, the first recommendation is that the legislation needs to split the withholding obligation between the issuer and the intermediary, depending on who faces the foreign person. As is the case with dividends tax, sections $64 \mathrm{G}$ and $64 \mathrm{H}$ of the Act split the withholding obligation between the company that initially pays the dividend to the beneficial owner and the RI transferring the dividend to the beneficial owner. Thus, the WTI legislation needs to have its own separate withholding provisions relating to the issuer and the intermediary.

The second recommendation which will fully complement the first recommendation is to define who can be the intermediary. From a WTI perspective, there is no restriction imposed as to the status of the parties who may enter into an agreement which is subject to WTI, and therefore the issuer for WTI purposes can be any person. From a dividends tax perspective, an RI is already defined in section $64 \mathrm{D}$ of the Act and the scope of who is included in the definition can be used as an exact replica for WTI.

When these recommendations fail, it is suggested that SARS provides clarity to the industry through issuing either an interpretation note or a practice note clearly stating who has the withholding obligation in different scenarios.

\section{Acknowledgements Competing interests}

The authors declare that they have no financial or personal relationships that may have inappropriately influenced them in writing this article.

\section{Authors' contributions}

C.H. was responsible for conceptualisation of the study, literature review, collection of data, and analysis and interpretation of results. M.B. performed literature review, analysis and interpretation of results. L.B. was responsible for literature review, analysis and interpretation of results.

\section{Ethical considerations}

This article followed all ethical standards for research without direct contact with human or animal subjects.

\section{Funding information}

This research received no specific grant from any funding agency in the public, commercial, or not-for-profit sectors.

\section{Data availability statement}

Data sharing is not applicable to this article as no new data were created or analysed in this study.

\section{Disclaimer}

The views and opinions expressed in this article are those of the authors and do not necessarily reflect the official policy or position of any affiliated agency of the authors.

\section{References}

Creswell, J. W., 2007, Qualitative inquiry and research design: Choosing among five approaches, 2nd edn., Sage, Thousand Oaks, CA.

Davis Tax Committee, 2016, Second and final report on base erosion and profit shifting for the minister of finance, viewed 12 March 2019, from http://www.taxcom.org. za/library.html.

Ger, B., 2015, 'The new interest Withholding Tax: What Attorneys need to know', De Rebus (552), 48-49.

HMRC (United Kingdom), 2016, SAIM 9078 - Deduction of tax: Yearly interest: The person by or through whom payment is made UK: HMRC, viewed 24 November 2018, from https://www.gov.uk/hmrc-internal-manuals/savings-and-investmentmanual/saim9078.

Horn, C., 2018, 'Withholding tax on interest: Practical difficulties for withholding agents', Master's thesis, College of Business and Economics, University of Johannesburg.

Hutchinson, T. \& Duncan, N., 2012, 'Defining and describing what we do: Doctrinal legal research', Deakin Law Review 17(1), 83-119, viewed 07 June 2017, from https://ojs.deakin.edu.au/index.php/dlr/article/view/70/75.

Knight, A. \& Ruddock, L., 2008, Advanced research methods in the built environment, Blackwell, Oxford, viewed 19 May 2017, from https://books.google.co.za/books? $\mathrm{h} \mid=$ en\& $\mid \mathrm{r}=\&$ id=vhRhPDBHArUC\&oi=fnd\&pg=PR11\&dq=Advanced+Research+Met hods+in+the+Built+Environment\&ots=YFLjLyC7U0\&sig=Icxvid7FRT7NgURuJ-QAa 566SNU\#v=onepage \& $q=$ doctrinal $\&=$ false.

Mckerchar, M., 2008, 'Philosophical paradigms, inquiry strategies and knowledge claims: Applying the principles of research design and conduct to taxation', eJournal of Tax Research 6(1), 5-22.

National Treasury, 2009, Explanatory memorandum on the taxation law amendment bill, viewed 12 November 2018, from http://www.treasury.gov.za/legislation/ bills/2009/Default.aspx. 
National Treasury, 2010, Explanatory Memorandum on the Taxation Laws Amendment Bill, Pretoria: National Treasury, pp. 48-69, viewed 25 March 2017, from http:// www.treasury.gov.za/legislation/bills/2010/Default.aspx.

Rossman, G. \& Rallis, S., 2003, Learning in the field: An introduction to qualitative research, Sage, Thousand Oaks, CA.

Riyami, T.A., 2015, 'Main approaches to educational research', International Journal of Innovation and Research in Educational Sciences 2(5), 412-416.

SARS, 2015, Comprehensive guide to dividends tax, viewed 04 November 2018, from http:// www.sars.gov.za/AllDocs/OpsDocs/Guides/LAPD-IT-G19\%20-\%20Comprehensive $\% 20$ Guide $\% 20$ to $\% 20$ Dividends $\% 20 T a x \% 20-\% 20$ External $\% 20$ Guide.pdf.

SARS, 2017, SARS - Withholding tax on interest, viewed 04 November 2018, from http://www.sars.gov.za/TaxTypes/WTI/Pages/default.aspx.

South Africa, 1962, Income Tax Act No. 58 of 1962, Government Printer, Pretoria.
South Africa, 2011, Tax Administration Act No. 28 of 2011, Government Printer, Pretoria.

Share Trading Transactions Totally Electronic Company (STRATE), 2017, Our services: Dematerialising your shares, viewed 12 March 2019, from STRATE: http://www. strate.co.za/our-services/dematerialising-your-shares.

USA Department of the Treasury, 2017, Withholding of tax on nonresident aliens and foreign entities. USA: Internal Revenue Service 2-4, viewed 04 March 2019, from https://www.irs.gov/pub/irs-pdf/p515.pdf.

USA Internal Revenue Services, 1986, The Internal Revenue Code USA: Internal revenue services, viewed 12 March 2019, from https://www.law.cornell.edu/ uscode/text/26/1441.

Young, J., 2015, 'Defining "withholding agent": When "everyone" is both too much and not enough', The Tax Adviser, viewed 24 November 2018, from http://www. thetaxadviser.com/issues/2015/jul/tax-clinic-08.html. 